\title{
PENERAPAN MODEL PEMBELAJARAN THINK PAIR SHARE DENGAN PENDEKATAN SCIENTIFIC UNTUK MENINGKATKAN AKTIVITAS SISWA KELAS X MIA 4 SMA NEGERI 22 MAKASSAR ${ }^{1}$
}

\author{
Nursaida Hardiyanti \\ Program Pascasarjana Universitas Negeri Makassar \\ Email: nursaidaht@gmail.com \\ Muhaedah Rasyid \\ Jurusan Kimia FMIPA Universitas Negeri Makassar \\ Halimah Husain \\ Jurusan Kimia FMIPA Universitas Negeri Makassar
}

\begin{abstract}
Abstrak: Penelitian ini adalah penelitian tindakan kelas ( PTK) dengan tujuan untuk mengetahui langkah-langkah penerapan model pembelajaran Think Pair Share dengan Pendekatan Scientific yang dapat meningkatkan aktivitas dan hasil belajar siswa kelas X MIA 4 SMA Negeri 22 Makassar. Penelitian ini dilaksanakan sebanyak dua siklus. Hasil penelitian menunjukkan bahwa langkah-langkah pada model pembelajaran tersebut yang dapat meningkatkan aktivitas belajar siswa adalah: (1) fase pendahuluan dengan menegaskan bahwa keberanian mengungkapkan pendapat masuk dalam komponen penilaian, (2) fase Think dengan menegaskan bahwa siswa harus memiliki pertanyaan(mengamati dan menanya), (3) fase pair dengan mengacak kembali pasangan belajar dan semua pasangan belajar agar lebih memperhatikan dan membimbing pasangannya (mengomunikasikan), (4) fase share dengan Memberikan nilai tambahan dan melakukan penunjukkan (Mengomunikasikan), (5) fase evaluasi dengan cara menunjuk secara acak siswa untuk menjawab pertanyaan, (6) fase penutup dan penghargaan dengan memberikan penghargaan dalam bentuk pujian dan hadiah bagi siswa yang paling aktif dan mengecek catatan siswa. Persentase aktivitas siswa meningkat dari $42,18 \%$ pada siklus I menjadi $62,06 \%$ pada siklus II. Adapun nilai rata-rata hasil belajar siswa yaitu 76,56 dengan persentase ketuntasan hasil belajar meningkat dari $46,87 \%$ pada siklus I menjadi $78,21 \%$ pada siklus II.
\end{abstract}

Kata Kunci: think pair share, pendekatan scientific, aktivitas belajar, hasil belajar,ikatan kimia

Pelajaran kimia merupakan bagian dari sains atau ilmu pengetahuan alam yang meliputi banyak konsep yang menuntut siswa untuk lebih memahami suatu konsep. Kenyataannya, dalam mempelajari konsep kimia siswa cenderung menghafal tanpa memahami maknanya. Sementara itu pengembangan konsep-konsep kimia semakin meningkat, sehingga pada akhirnya menyebabkan kejenuhan dan kesulitan siswa dalam mempelajari kimia. Hal ini di

\footnotetext{
${ }^{1}$ Makalah dipresentasikan dalam Seminar Nasional "Tellu Cappa” yang diselenggarakan oleh Himpunan Awardee LPDP UNM dan Formaster Sulsel-Malang pada 16-17 September 2017.
} 
dukung beberapa fakta di dalam kelas yaitu kurangnya keaktifan siswa dalam proses pembelajaran yang ditunjukkan dengan kurangnya pertanyaan maupun tanggapan yang ditujukan untuk guru, dankurangnya perhatian siswa pada materi yang diajarkan. Sebagai alternatif pemecahan masalah maka perlu diterapkan suatu modelpembelajaran yang inovatif, menarik, mendorong keaktifan, kerjasama dan memaksimalkan keterlibatan siswa. Salah satu model pembelajaran yang dapat meningkatkan aktivitas siswa yaitu model pembelajaran think pair share.

Berdasarkan hasil observasi penulis di SMA Negeri 22 Makassar secara umum siswa menganggap pelajaran kimia sebagai pelajaran yang cukup sulit dan membosankan. Metode yang digunakan guru dalam mengajar tidak bervariasi, dalam kelas guru lebih banyak menjelaskan dibandingkan dengan siswa. Hal tersebut mengakibatkan siswa hanya mendengar penjelasan guru dan tidak berusaha untuk memikirkan hal-hal yang telah dijelaskan tersebut secara mendalam serta tidak mengungkapkan hal-hal yang kurang dimengerti pada saat proses pembelajaran.

Berdasarkan keterangan dari guru kimia di SMA Negeri 22 Makassar, masih terdapat siswa yang mengalami kesulitan dalam memahami materi pelajaran kimia, Sangat sedikit siswa yang hasil ulangan hariannya yang mencapai nilai kriteria ketuntasan minimal (KKM) yaitu 75, terutama untuk materi yang berkaitan dengan ikatan kimia karena materi ikatan kimia masih dianggap sulit dipahami oleh siswa, sehingga berdampak terhadap minat, aktivitas dan hasil belajar siswa.

Objek dalam penelitian ini adalah kelas X MIA 4 karena berdasarkan observasi yang dilakukan pada kelas tersebut menunjukkan bahwa kualitas pembelajarannya tergolong masih rendah yang dapat dilihat dari kurangnya aktivitas siswa dalam mengikuti proses pembelajaran kimia jika di bandingkan dengan kelas MIA yang lain. Selain itudata hasil belajar pada materi kimia sebelumnya yaitu materi struktur atom dan sistem periodik masih rendah, dari 32 siswa terdapat $28 \%$ siswa yang dinyatakan tuntas dan $72 \% \%$ siswa yang dinyatakan tidak tuntas sesuai dengan nilai KKM. Adanya hasil belajar siswa kelas X MIA 4 yang kurang optimal, jelas mengindikasikan adanya permasalahan serius dalam kegiatan pembelajaran kimiayang harus segera didapatkan solusinya, sehingga perlu dilakukan perbaikan kualitas pembelajaran.

Untuk mengatasi permasalahan tersebut maka digunakan model pembelajaran think pair share. Model pembelajaran think pair shareadalah model pembelajaran yang dapat melatih dan mengembangkan kemampuan berpikir serta aktivitas siswa. Siswa dapat membangun pengetahuannya sendiri melalui eksplorasi dan pengetahuan siswa juga dapat 
berkembang melalui transfer pola pikir dengan siswa yang lain, sehingga siswa menggabungkan dan membandingkan pola pikirnya dengan pola pikir temannya. Selain itu model pembelajaran ini juga dapat merangsang kemampuan berpikir tingkat tinggi. Potensi yang dimiliki siswa digali semaksimal mungkin sehingga masalah yang dia dapatkan tergantung dari hasil pemikiran mereka sehingga siswa diharapkan dapat berpikir secara optimal. Model pembelajaran ini juga sejalan dengan pendekatan scientificyang menjadi ciri khas dari Kurikulum 2013 (Chotimah, 2009).

Pendekatan scientificmencakup komponenmengamati, menanya, menalar, mencoba dan mengomunikasikan atau mempresentasikan yang seharusnya diadaptasikan dalam sintaks model pembelajaran. Maka, dengan diterapkannya model pembelajaran think Pair Share dengan pendekatan scientific ini diharapkan dapat meningkatkan minat siswa untuk belajar menemukan sendiri jawaban dari masalah yang dipertanyakan dan interaksi dengan temannya juga akan mendorong siswa semakin aktif dan hasil belajarnya lebih baik(Kurinasih dan sani, 2014).

Model pembelajaran think pair share dengan pendekatan scientific dipandang cukup sesuai dengan materi ikatan kimia yang dipilih dalam penelitian ini.Melalui model pembelajaran ini diharapkan siswa merasa bahwa pelajaran kimia terutama materi ikatan kimia tidak sesulit yang mereka bayangkan karena dengan model pembelajaran ini mereka mampu memecahkan masalah sendiri sehingga rasa tertarik untuk mempelajari dan memahami kimia akan tumbuh. Penelitian yang dilakukan merupakan penelitian tindakan kelas karena pada kelas X MIA 4 tersebut sangat perlu ditingkatkan kualitas pembelajarannya melalui tindakan-tindakan yang diberikan yang dapat meningkatkan aktivitas dan hasil belajarnya.

Berdasarkan hasil penelitian yang dilakukan oleh Wahyuni (2012), hasil belajar matematika mengalami peningkatan setelah dilakukan pembelajaran melalui Model Pembelajaran Kooperatif Tipe TPS (think pair share). Begitupun penelitian yang dilakukan oleh Mufidah (2013), yangmenunjukkan bahwa penerapan model pembelajaran kooperatif tipe TPS dapat meningkatkan aktivitas siswa untuk mengembangkan pengetahuan mereka tentang pokok bahasan matriks.

Berdasarkan uraian di atas, maka peneliti termotivasi mengadakanpenelitian tindakan kelas yang berjudul Penerapan Model Pembelajaran Think Pair Share dengan Pendekatan Scientific Untuk Meningkatkan Aktivitas dan Hasil Belajar Siswa Kelas X MIA 4 SMA Negeri 22 Makassar Studi Pada Materi Pokok Ikatan Kimia. 


\section{METODE PENELITIAN}

Penelitian ini adalah penelitian tindakan kelas (classroom action research) dengan tahapan pelaksanaan meliputi tahap perencanaan, pelaksanaan tindakan, observasi dan refleksi.Subyek penelitian ini adalah siswa kelas X MIA 4 SMA Negeri 22 Makassar semester ganjil dengan siswa sebanyak 32 orang.

Penelitian tindakan kelas ini dilaksanakan dalam dua siklus dengan mengacu pada indikator keberhasilan. Penelitian ini dilakukan sebanyak dua siklus. Setiap siklus terdiri atas 2 kali pertemuan untuk penyampaian materi dan1kali pertemuan untuk tes hasil belajar. Setiap pertemuan dilaksanakan dalam3 x 45 menit. Jika siklus pertama belum mencapai indikator keberhasilan maka siklus kedua akan diadakan.Siklus kedua ini merupakan perbaikan dari siklus satu dan disesuaikan dengan tujuan yang ingin dicapai. Gambaran umum yang dilakukan pada setiap siklus yaitu perencanaan, pelaksanaan, pengamatan, dan refleksi.

Instrumen penelitian yang digunakan dalam penelitian ini adalah sebagai berikut:

\section{Lembar observasi aktivitas belajar siswa}

Lembar observasi aktivitas belajar siswa adalah lembar observasi yang digunakan untuk mengukur aktivitas belajar siswa selama proses pembelajaran. Lembar observasi ini disesuaikan dengan sintaks dari model pembelajaran think pair share dengan pendekatan scientific. Adapun kegiatan yang diamati pada lembar observasi yaitu sebagai berikut:

a. visual activities yaitu siswa memperhatikan penjelasan guru dengan serius, membaca buku mengenai materi yang sedang dipelajari, spontan/langsung bergabung dengan pasangannya yang telah ditentukan, membaca literatur untuk menyempurnakan jawaban secara berpasangan dan memperhatikan saat pasangan lain sedang menyampaikan hasil diskusi dengan pasangannya.

b. oral activitiesyaitu siswa mengajukan pertanyaan tentang bagian dari materi yang tidak dipahami dari apa yang diamati, berdiskusi dengan pasangannya untuk menyatukan pendapat, mengangkat tangan saat guru memberikan kesempatan menyampaikan hasil diskusi dengan pasangannya keseluruh pasangan lain, mengangkat tangan saat guru memberikan kesempatan untuk menanggapi jawaban yang telah dipaparkan oleh pasangan yang sedang memaparkan jawabannya, menjelaskan ulang jawaban yang telah disepakati oleh semua pasangan, menjawab pertanyaan lain yang ditanyakan oleh guru secara mandiri dan memberi kesimpulan di akhir pembelajaran. 
c. writing activitiesyaitu siswa menuliskan jawaban dari hasil pemikiran sendiri, menuliskan jawaban yang telah disepakati secara berpasangan, menuliskan jawaban yang telah disepakati seluruh pasangan dan siswa menulis kesimpulan yang telah disampaikan.

d. mental activities yaitu siswa berusaha untuk menyelesaikan sendiri jawaban dari pertanyaan yang diberikan.

Lembar observasi ini berbentuk turus (tally) dengan ketentuan setiap siswa melakukan aktivitas yang diamati maka akan diberikan satu turus. Lembar observasi ini diisi oleh dua orang observer yang telah dipilih oleh peneliti. Lembar observasi aktivitas belajar siswa ini dapat merekam segala aktivitas yang dilakukan oleh siswa dalam proses pembelajaran.

Teknik analisis data yang digunakan untuk setiap komponen instrumen penelitian adalah sebagai berikut:

\section{Lembar observasi aktivitas belajar}

Teknik analisis aktivitas belajar siswa menggunakan analisis deskriptif. Terdapat dua rumus yaitu perhitungan persentase aktivitas siswa per item dan perhitungan rata-rata aktivitas siswa secara keseluruhan item dalam tiap pertemuannya. Berikut adalah rumus yang digunakan dalam perhitungan aktivitas belajar siswa.

$$
\text { Persentase aktivitas belajar siswa per indikator }=\frac{\text { jumlah aktivitas yang muncul }}{\text { jumlah total siswa }} \times 100 \%
$$

Persentase aktivitas belajar per fase pembelajaran $=\frac{\sum \text { Persentase aktivitas belajar siswa per indikator }}{\text { Jumlah Total Indikator }}$

Persentase aktivitas belajar per pertemuan $=\frac{\sum \text { Persentase aktivitas belajar siswa per fase }}{\text { Jumlah Total Fase }}$

Persentase aktivitas belajar persiklus $=\frac{\sum \text { Persentase aktivitas belajar siswa per pertemuan }}{\text { Jumlah Total Pertemuan }}$

Tabel 1 Kategori Aktivitas Belajar Siswa

\begin{tabular}{|c|c|}
\hline Skor Rata-rata & Kategori \\
\hline $81 \%-100 \%$ & Sangat baik \\
\hline $61 \%-80 \%$ & Baik \\
\hline $41 \%-60 \%$ & Cukup \\
\hline $21 \%-40 \%$ & Kurang \\
\hline$\leq 20 \%$ & Kurang sekali \\
\hline
\end{tabular}

Sumber: Desi (2006).

Indikator yang menunjukkan keberhasilan pelaksanaan tindakan ini dapat dilihat sebagai berikut:

\section{Aktivitas Belajar Siswa}


Indikator keberhasilan penelitian ini dari segi aktivitas adalah apabila terjadi peningkatan aktivitas belajar siswa dari siklus I ke siklus II. Tingkat keberhasilan aktivitas belajar ditinjau dari persentase aktivitas belajar mencapai $61 \%$ atau minimal telah mencapai kategori baik.

\section{HASIL DAN PEMBAHASAN}

\section{AktivitasBelajar}

1. Siklus I

Berdasarkan penyajian dan analisis data lembar observasi aktivitas belajar siswa kelas X MIA 4 SMA Negeri 22 Makassar pada materi ikatan kimia (dapat dilihat pada lampiran III), diperoleh persentase rata-rata aktivitas belajar siswa pada siklus I yaitu $41.18 \%$ dengan predikat cukup. Rincian data kuantitatif hasil observasi aktivitas belajar siswa dapat dilihat pada Tabel 2

Tabel 2 Hasil observasi aktivitas belajar siswa pada siklus I

\begin{tabular}{|c|c|c|c|c|c|c|c|c|}
\hline \multirow{3}{*}{ No } & \multirow{3}{*}{$\begin{array}{c}\text { Fase } \\
\text { pembelaj } \\
\text { aran }\end{array}$} & \multicolumn{7}{|c|}{ Persentase Aktivitas $\quad$ Siklus I (\%) } \\
\hline & & \multicolumn{2}{|c|}{ Per pertemuan } & \multirow{2}{*}{$\begin{array}{c}\text { Rata- } \\
\text { rata }\end{array}$} & \multirow{2}{*}{$\begin{array}{l}\text { Per } \\
\text { fase }\end{array}$} & \multirow{2}{*}{ Predikat } & \multirow{2}{*}{$\begin{array}{c}\text { Per } \\
\text { siklus }\end{array}$} & \multirow{2}{*}{ predikat } \\
\hline & & Pert. I & Pert II & & & & & \\
\hline 1 & \multirow{3}{*}{$\begin{array}{c}\text { Fase I } \\
\text { pendahul } \\
\text { uan }\end{array}$} & 65.62 & 65.62 & 65.62 & \multirow{3}{*}{49.99} & \multirow{3}{*}{ Cukup } & \multirow{20}{*}{42.18} & \multirow{20}{*}{ Cukup } \\
\hline 2 & & 64.06 & 67.18 & 67.18 & & & & \\
\hline 3 & & 15.62 & 21.87 & 18.74 & & & & \\
\hline 4 & \multirow{4}{*}{$\begin{array}{c}\text { Fase II } \\
\text { Think }\end{array}$} & 62.50 & 62.50 & 62.50 & \multirow{4}{*}{47.62} & \multirow{4}{*}{ Cukup } & & \\
\hline 5 & & 26.56 & 29.68 & 28.12 & & & & \\
\hline 6 & & 56.25 & 53.12 & 54.68 & & & & \\
\hline 7 & & 40.62 & 50.00 & 45.31 & & & & \\
\hline 8 & \multirow{4}{*}{$\begin{array}{c}\text { Fase III } \\
\text { Pair }\end{array}$} & 64.06 & 67.18 & 65.62 & \multirow{4}{*}{66.20} & \multirow{4}{*}{ Baik } & & \\
\hline 9 & & 62.50 & 62.50 & 62.50 & & & & \\
\hline 10 & & 68.75 & 70.31 & 69.53 & & & & \\
\hline 11 & & 67.18 & 67.18 & 67.18 & & & & \\
\hline 12 & \multirow{5}{*}{$\begin{array}{c}\text { Fase IV } \\
\text { Share }\end{array}$} & 34.37 & 34.37 & 34.37 & \multirow{5}{*}{44.99} & \multirow{5}{*}{ Cukup } & & \\
\hline 13 & & 31.25 & 37.50 & 34.37 & & & & \\
\hline 14 & & 21.87 & 28.12 & 24.99 & & & & \\
\hline 15 & & 67.18 & 68.75 & 67.96 & & & & \\
\hline 16 & & 67.18 & 59.37 & 63.27 & & & & \\
\hline 17 & $\begin{array}{c}\text { Fase V } \\
\text { Evaluasi }\end{array}$ & 31.25 & 28.12 & 29.68 & 29.68 & Kurang & & \\
\hline 18 & \multirow{3}{*}{$\begin{array}{c}\text { Fase VI } \\
\text { Penutup } \\
\text { dan } \\
\text { Pengharg } \\
\text { aan }\end{array}$} & 6.25 & 6.25 & 6.25 & \multirow{3}{*}{27.33} & \multirow{3}{*}{ Kurang } & & \\
\hline 19 & & 15.62 & 21.87 & 18.74 & & & & \\
\hline 20 & & 54.68 & 59.37 & 57.02 & & & & \\
\hline
\end{tabular}

Setiap aktivitas yang diamati pada tiap fase dikelompokkan ke dalam beberapa kelompok indikator aktivitas yaitu visual activities, oral activities, writing activities dan 
mental activities. Berdasarkan hasil penyajian dan analisis aktivitas belajar siswa secara teori (dapat dilihat pada Lampiran III), diperoleh persentase rata-rata aktivitas secara teori pada siklus I yaitu $50.08 \%$. Rincian data kuantitatif hasil observasi aktivitas belajar siswa secara teori dapat dilihat pada Tabel 3

Tabel 3 Hasil Observasi Aktivitas Belajar Siswa secara Teori pada Siklus I

\begin{tabular}{|c|c|c|}
\hline Indikator Aktivitas & Persentase(\%) & Predikat \\
\hline Visual Activities & 63.90 & Baik \\
\hline Oral Activities & 34.26 & Kurang \\
\hline Writing Activities & 59.36 & Cukup \\
\hline Mental Activities & 54.68 & Cukup \\
\hline
\end{tabular}

Persentase terendah dari aktivitas belajar siswa berada pada aspek oral activities. Oral activities adalah aspek aktivitas yang berfokus pada kemampuan dalam menyampaikan pendapat, tanggapan, solusi, pertanyaan dan segala sesuatu yang berkaitan dengan komunikasi antar siswa.

\section{Refleksi Siklus I}

Berdasarkan hasil penyajian dan analisis data pada lampiran III terlihat bahwa rata-rata aktivitas belajar siswa pada siklus I masih berada pada kategori cukup. Hal ini disebabkan langkah-langkah model pembelajaran think pair sharedengan pendekatan scientific pada siklus I belum secara maksimal dapat meningkatkan aktivitas siswa sehingga perlu direfleksi. Hasil refleksi siklus I inilah yang dijadikan sebagai acuan untuk merencanakan tindakan yang akan dilaksanakan di siklus II sehingga dapat terjadi peningkatan aktivitas belajar siswa Adapun hasil refleksi aktivitas belajar yang dilakukan pada siklus I disajikan pada tabel 4.

Tabel 4 Hasil Refleksi pada pelaksanaan siklus I

\begin{tabular}{|l|l|l|l|}
\hline \multicolumn{1}{|c|}{ Fase } & \multicolumn{1}{|c|}{ Siklus I } & \multicolumn{1}{c|}{ Refleksi } & \multicolumn{1}{c|}{ Tindakan (Siklus II) } \\
\hline $\begin{array}{l}\text { Fase I } \\
\text { Pendahuluan }\end{array}$ & $\begin{array}{l}\text { Menjawab pertanyaan } \\
\text { apersepsi yang diajukan oleh } \\
\text { guru }\end{array}$ & $\begin{array}{l}\text { Hanya 18.74\% } \\
\text { siswa yang } \\
\text { menjawab } \\
\text { pertanyaan } \\
\text { apersepsi dari guru }\end{array}$ & $\begin{array}{l}\text { Guru menegaskan bahwa } \\
\text { keberanian mengungkapkan } \\
\text { pendapat di depan umum } \\
\text { sangat penting dan juga } \\
\text { masuk dalam komponen } \\
\text { penilaian guru }\end{array}$ \\
\hline $\begin{array}{l}\text { Fase } 2 \\
\text { Think }\end{array}$ & $\begin{array}{l}\text { Mengajukan pertanyaan dari } \\
\text { materi yang tidak dipahami } \\
\text { dari apa yang diamati }\end{array}$ & $\begin{array}{l}\text { Hanya 28.12\% } \\
\text { siswa yang berani } \\
\text { mengajukan } \\
\text { pertanyaan dari } \\
\text { materi yang tidak } \\
\text { dipahami }\end{array}$ & $\begin{array}{l}\text { Guru menegaskan bahwa } \\
\text { siswa harus memiliki } \\
\text { pertanyaan dari materi yang } \\
\text { tidak pahami dari apa yang } \\
\text { di amati }\end{array}$ \\
\cline { 2 - 4 } & $\begin{array}{l}\text { Menuliskan jawaban dari } \\
\text { hasil pemikiran sendiri }\end{array}$ & $\begin{array}{l}\text { Hanya 45.31\% } \\
\text { siswa yang } \\
\text { menuliskan }\end{array}$ & $\begin{array}{l}\text { Guru menegaskan bahwa } \\
\text { sebelum berdiskusi dengan } \\
\text { pasangannya masing-masing }\end{array}$ \\
\cline { 2 - 4 } & \multicolumn{2}{|l}{} \\
\end{tabular}




\begin{tabular}{|c|c|c|c|}
\hline Fase & Siklus I & Refleksi & Tindakan (Siklus II) \\
\hline & & $\begin{array}{l}\text { jawaban dari hasil } \\
\text { pemikiran sendiri } \\
\text { padahal jawaban } \\
\text { yang dituliskan } \\
\text { nantinya akan } \\
\text { disikusikan } \\
\text { bersama } \\
\text { pasangannya } \\
\end{array}$ & $\begin{array}{l}\text { terlebih dahulu semua siswa } \\
\text { harus menuliskan jawaban } \\
\text { sendiri yang tidak akan } \\
\text { dituntut benar atau salah } \\
\text { dari yang jawaban yang } \\
\text { dituliskan karena kegiatan } \\
\text { itu termasuk dalam } \\
\text { komponen penilaian }\end{array}$ \\
\hline $\begin{array}{l}\text { Fase } 3 \\
\text { Pair }\end{array}$ & $\begin{array}{l}\text { spontan/ langsung bergabung } \\
\text { dengan pasangannya yang } \\
\text { telah ditentukan, membaca } \\
\text { literatur untuk } \\
\text { menyempurnakan jawaban } \\
\text { secara berpasangan, } \\
\text { berdiskusi dengan } \\
\text { pasangannya untuk } \\
\text { menyatukan pendapat dan } \\
\text { menuliskan jawaban yang } \\
\text { telah disepakati oleh } \\
\text { pasangan. } \\
\text { (aktivitas belajar butir } 8 \\
\text { hingga 11) (dapat dilihat } \\
\text { pada lampiran III) }\end{array}$ & $\begin{array}{l}\text { Hasil observasi } \\
\text { keempat aktivitas } \\
\text { belajar ini } \\
\text { menunjukkan } \\
\text { bahwa pada fase } \\
\text { Pairing mencapai } \\
66.20 \% \text { dengan } \\
\text { kategori baik. } \\
\text { Hanya saja } \\
\text { interaksi kerja } \\
\text { sama dengan } \\
\text { pasangan belajar } \\
\text { belum terjalin } \\
\text { dengan baik dan } \\
\text { siswa yang } \\
\text { memiliki } \\
\text { kemampuan } \\
\text { akademik yang } \\
\text { lebih tinggi masih } \\
\text { mendominasi } \\
\text { aktivitas belajar } \\
\text { utamanya dalam } \\
\text { mengerjakan } \\
\text { LKPD }\end{array}$ & $\begin{array}{l}\text { Guru mengacak kembali } \\
\text { pasangan belajar agar siswa } \\
\text { terlatih untuk bekerja sama } \\
\text { dengan semua teman kelas } \\
\text { mereka sehingga interaksi } \\
\text { sosial lebih meningkat dan } \\
\text { waktu yang digunakan pada } \\
\text { fase Pairing ditambah dan } \\
\text { Guru menekankan kepada } \\
\text { semua pasangan belajar } \\
\text { agar lebih memperhatikan } \\
\text { dan membimbing } \\
\text { pasangannya saat diskusi } \\
\text { sehingga setiap siswa } \\
\text { mengetahui jawaban dari } \\
\text { semua soal yang diberikan. }\end{array}$ \\
\hline $\begin{array}{l}\text { Fase } 4 \\
\text { Share }\end{array}$ & $\begin{array}{l}\text { Mengangkat tangan saat guru } \\
\text { memberikan kesempatan } \\
\text { untuk menyampaikan hasil } \\
\text { pemikiran dengan } \\
\text { pasangannya ke seluruh } \\
\text { pasangan }\end{array}$ & $\begin{array}{l}\text { Hanya } 34.37 \% \\
\text { siswa yang } \\
\text { berani } \\
\text { menyampaikan } \\
\text { hasil pemikiran } \\
\text { dengan } \\
\text { pasangannya ke } \\
\text { seluruh pasangan } \\
\text { karena } \\
\text { kurangnya } \\
\text { kepecayaan diri } \\
\text { dari siswa }\end{array}$ & $\begin{array}{l}\text { Guru menegaskan bahwa } \\
\text { kemapuan mengemukakan } \\
\text { pendapat didepan umum } \\
\text { sangat penting dan juga } \\
\text { menegaskan bagi siswa } \\
\text { yang berani menyampaikan } \\
\text { hasil pemikiran dengan } \\
\text { pasangannya ke seluruh } \\
\text { pasangan akan diberi nilai } \\
\text { tambahan dan bagi siswa } \\
\text { yang paling aktif dalam } \\
\text { proses pembelajaran } \\
\text { berlangsung akan diberikan } \\
\text { hadiah diakhir } \\
\text { pembelajaran dan akan } \\
\text { dilakukan penunjukkan jika } \\
\text { tidak ada yang berani } \\
\text { mengemukakan } \\
\text { pendapatnya }\end{array}$ \\
\hline
\end{tabular}




\begin{tabular}{|c|c|c|c|}
\hline Fase & Siklus I & Refleksi & Tindakan (Siklus II) \\
\hline & $\begin{array}{l}\text { Mengangkat tangan saat } \\
\text { guru memberikan } \\
\text { kesempatan untuk } \\
\text { menanggapi jawaban yang } \\
\text { telah disepakati oleh } \\
\text { pasangan yang sedang } \\
\text { memaparkan jawabannya } \\
\text { dikarenakan kurangnya } \\
\text { kepercayaan diri dari siswa }\end{array}$ & $\begin{array}{l}\text { Hanya } 34.37 \% \\
\text { siswa yang } \\
\text { berani } \\
\text { menanggapi } \\
\text { jawaban yang } \\
\text { telah disepakati } \\
\text { oleh pasangan } \\
\text { yang sedang } \\
\text { memaparkan } \\
\text { jawabannya } \\
\text { dikarenakan } \\
\text { kurangnya } \\
\text { kepercayaan diri } \\
\text { dari siswa }\end{array}$ & $\begin{array}{l}\text { Guru Menegaskan bahwa } \\
\text { kemampuan } \\
\text { mengemukakan pendapat } \\
\text { didepan umum sangat } \\
\text { penting dan juga } \\
\text { menegaskan bahwa bagi } \\
\text { siswa yang berani } \\
\text { menanggapi jawaban yang } \\
\text { telah disepakati oleh } \\
\text { pasangan yang sedang } \\
\text { memaparkan jawabannya } \\
\text { akan diberi nilai tambahan } \\
\text { dan bagi siswa yang paling } \\
\text { aktif dalam proses } \\
\text { pembelajaran berlangsung } \\
\text { akan diberikan hadiah } \\
\text { diakhir pembelajaran dan } \\
\text { akan dilakukan penunjukkan } \\
\text { jika tidak ada yang berani } \\
\text { mengemukakan } \\
\text { pendapatnya }\end{array}$ \\
\hline & $\begin{array}{l}\text { Menjelaskan ulang jawaban } \\
\text { yang telah disepakati oleh } \\
\text { semua pasangan }\end{array}$ & $\begin{array}{l}\text { Hanya 24.99\% } \\
\text { siswa yang dapat } \\
\text { menjelaskan } \\
\text { ulang jawaban } \\
\text { yang telah } \\
\text { disepakati oleh } \\
\text { semua pasangan }\end{array}$ & $\begin{array}{l}\text { Guru meminta siswa untuk } \\
\text { menuliskan jawaban yang } \\
\text { telah disepakati oleh } \\
\text { seluruh pasangan dan } \\
\text { menegaskan bahwa bagi } \\
\text { siswa yang berani } \\
\text { menjelaskan ulang jawaban } \\
\text { yang telah disepakati oleh } \\
\text { semua pasangan akan diberi } \\
\text { nilai tambahan dan bagi } \\
\text { siswa yang paling aktif } \\
\text { dalam proses pembelajaran } \\
\text { berlangsung akan diberikan } \\
\text { hadiah diakhir } \\
\text { pembelajaran. dan akan } \\
\text { dilakukan penunjukkan jika } \\
\text { tidak ada yang berani } \\
\text { mengemukakan } \\
\text { pendapatnya }\end{array}$ \\
\hline $\begin{array}{l}\text { Fase } 5 \\
\text { Evaluasi }\end{array}$ & $\begin{array}{l}\text { Menjawab pertanyaan lain } \\
\text { yang ditanyakan oleh guru } \\
\text { secara mandiri }\end{array}$ & $\begin{array}{lr}\text { Hanya } 29.68 \% \\
\text { siswa yang } \\
\text { berani Menjawab } \\
\text { pertanyaan lain } \\
\text { yang ditanyakan } \\
\text { oleh guru secara } \\
\text { mandiri }\end{array}$ & $\begin{array}{l}\text { Guru menunjuk secara acak } \\
\text { siswa untuk menjawab } \\
\text { pertanyaan yang diberikan } \\
\text { oleh guru secara mandiri } \\
\text { dan menegaskan bahwa } \\
\text { bagi siswa yang } \\
\text { jawabannya benar akan } \\
\text { mendapatkan } \\
\text { tambahan }\end{array}$ \\
\hline $\begin{array}{l}\text { Fase } 6 \\
\text { Penutup dan } \\
\text { penghargaan }\end{array}$ & $\begin{array}{l}\text { Menerima Penghargaan dari } \\
\text { guru }\end{array}$ & 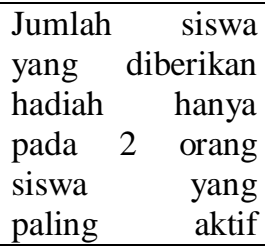 & $\begin{array}{l}\text { Guru menegaskan bahwa } \\
\text { dipertemuan selanjutnya } \\
\text { ada } 6 \text { siswa paling aktif } \\
\text { yang akan diberikan hadiah } \\
\text { diakhir pembelajaran }\end{array}$ \\
\hline
\end{tabular}




\begin{tabular}{|l|l|l|l|}
\hline Fase & \multicolumn{1}{|c|}{ Siklus I } & \multicolumn{1}{c|}{ Refleksi } & \multicolumn{1}{c|}{ Tindakan (Siklus II) } \\
\hline & \multicolumn{1}{|c|}{$\begin{array}{l}\text { sehingga } \\
\text { persentase } \\
\text { aktivitasnya } \\
\text { hanya 6,25\% }\end{array}$} & \\
& $\begin{array}{l}\text { Berani untuk memberikan } \\
\text { kesimpulan diakhir } \\
\text { pembelajaran }\end{array}$ & $\begin{array}{l}\text { Hanya 18.74\% } \\
\text { siswa yang } \\
\text { berani } \\
\text { memberikan } \\
\text { kesimpulan } \\
\text { diakhir } \\
\text { pembelajaran }\end{array}$ & $\begin{array}{l}\text { Guru menunjuk secara acak } \\
\text { dan menegaskan bagi siswa } \\
\text { yang berani untuk } \\
\text { memberikan kesimpulan } \\
\text { diakhir pembelajaran akan } \\
\text { diberikan nilai tambahan }\end{array}$ \\
& $\begin{array}{l}\text { Menuliskan kesimpulan } \\
\text { yang telah diberikan oleh } \\
\text { temannya }\end{array}$ & $\begin{array}{l}\text { Hanya 57.02\% } \\
\text { siswa yang } \\
\text { Menuliskan } \\
\text { kesimpulan yang } \\
\text { telah diberikan } \\
\text { oleh temannya }\end{array}$ & $\begin{array}{l}\text { Guru menegaskan bahwa } \\
\text { kesimpulan } \\
\text { pembelajaran merupakan } \\
\text { bagian yang terpenting } \\
\text { untuk bisa lulus dalam tes } \\
\text { akhir hasil belajar dan guru } \\
\text { mengecek catatan siswa. }\end{array}$ \\
\hline
\end{tabular}

Fokus refleksi yang dilakukan adalah bagaimana mengaktifkan siswa sehingga bisa bekerja sama dengan baik dalam pasangan dan berani memberikan tanggapan dalam berdiskusi. Oleh karena itu, perbaikan yang dilakukan pada siklus II lebih ditekankan pada pengelolaan kelas agar proses belajar mengajar dapat berjalan lebih baik dari pelaksanaan siklus I.

\section{Siklus II}

Berdasarkan Penyajian dan analisis data lembar observasi aktivitas belajar siswa kelas X MIA 4 SMA Negeri 22 Makassar pada materi ikatan kimia (dapat dilihat pada lampiran III), diperoleh persentase rata-rata aktivitas belajar siswa pada siklus II yaitu $62.06 \%$ dengan predikat baik. Rincian data kuantitatif hasil observasi aktivitas belajar siswa dapat dilihat pada Tabel 5

Tabel 5 Hasil observasi aktivitas belajar siswa pada siklus II

\begin{tabular}{|c|c|c|c|c|c|c|c|c|}
\hline \multirow{3}{*}{ No } & \multirow{3}{*}{$\begin{array}{c}\text { Fase } \\
\text { pembela } \\
\text { jaran }\end{array}$} & \multicolumn{7}{|c|}{ Persentase Aktivitas Siklus II (\%) } \\
\hline & & \multicolumn{2}{|c|}{ Per pertemuan } & \multirow{2}{*}{$\begin{array}{c}\text { Rata- } \\
\text { rata }\end{array}$} & \multirow{2}{*}{$\begin{array}{l}\text { Per } \\
\text { fase }\end{array}$} & \multirow{2}{*}{ Predikat } & \multirow{2}{*}{$\begin{array}{c}\text { Per } \\
\text { siklus }\end{array}$} & \multirow{2}{*}{ predikat } \\
\hline & & Pert I & Pert.II & & & & & \\
\hline 1 & \multirow{3}{*}{$\begin{array}{c}\text { Fase I } \\
\text { pendahul } \\
\text { uan }\end{array}$} & 71.87 & 73.43 & 72.65 & \multirow{3}{*}{64.05} & \multirow{3}{*}{ Baik } & \multirow{15}{*}{62.06} & \multirow{15}{*}{ Baik } \\
\hline 2 & & 70.31 & 75.00 & 72.65 & & & & \\
\hline 3 & & 46.87 & 46.87 & 46.87 & & & & \\
\hline 4 & \multirow{4}{*}{$\begin{array}{c}\text { Fase II } \\
\text { Think }\end{array}$} & 71.87 & 71.87 & 71.87 & \multirow{4}{*}{65.62} & \multirow{4}{*}{ Baik } & & \\
\hline 5 & & 56.25 & 56.25 & 56.25 & & & & \\
\hline 6 & & 70.31 & 70.31 & 70.31 & & & & \\
\hline 7 & & 65.62 & 62.50 & 64.06 & & & & \\
\hline 8 & \multirow{4}{*}{$\begin{array}{l}\text { Fase III } \\
\text { Pairing }\end{array}$} & 78.12 & 78.12 & 78.12 & \multirow{4}{*}{72.65} & \multirow{4}{*}{ Baik } & & \\
\hline 9 & & 71.87 & 70.31 & 71.09 & & & & \\
\hline 10 & & 73.43 & 71.87 & 72.65 & & & & \\
\hline 11 & & 68.75 & 68.75 & 68.75 & & & & \\
\hline 12 & \multirow{4}{*}{ Fase IV } & 73.43 & 73.43 & 73.43 & \multirow{4}{*}{64.99} & \multirow{4}{*}{ Baik } & & \\
\hline 13 & & 65.62 & 65.62 & 65.62 & & & & \\
\hline 14 & & 37.50 & 37.50 & 37.50 & & & & \\
\hline 15 & & 75.00 & 75.00 & 75.00 & & & & \\
\hline
\end{tabular}




\begin{tabular}{|c|c|c|c|c|c|c|c|c|}
\hline \multirow{3}{*}{ No } & \multirow{4}{*}{$\begin{array}{c}\text { Fase } \\
\text { pembela } \\
\text { jaran }\end{array}$} & \multicolumn{4}{|c|}{ Persentase Aktivita } & \multicolumn{3}{|c|}{ Siklus II (\%) } \\
\hline & & \multicolumn{2}{|c|}{ Per pertemuan } & \multirow{2}{*}{$\begin{array}{c}\text { Rata- } \\
\text { rata }\end{array}$} & \multirow{3}{*}{$\begin{array}{l}\text { Per } \\
\text { fase }\end{array}$} & \multirow{3}{*}{ Predikat } & \multirow{7}{*}{$\begin{array}{c}\text { Per } \\
\text { siklus }\end{array}$} & \multirow{7}{*}{ predikat } \\
\hline & & Pert I & Pert.II & & & & & \\
\hline 16 & & 73.43 & 73.43 & 73.43 & & & & \\
\hline 17 & $\begin{array}{l}\text { Fase V } \\
\text { Evaluasi }\end{array}$ & 53.12 & 53.12 & 53.12 & 53.12 & Cukup & & \\
\hline 18 & \multirow{3}{*}{$\begin{array}{l}\text { Fase VI } \\
\text { Penutup } \\
\text { dan } \\
\text { Pengharg } \\
\text { aan }\end{array}$} & 18.75 & 18.75 & 18.75 & \multirow{3}{*}{39.29} & \multirow{3}{*}{ Kurang } & & \\
\hline 19 & & 31.25 & 31.25 & 31.25 & & & & \\
\hline 20 & & 64.06 & 71.87 & 67.96 & & & & \\
\hline
\end{tabular}

Secara detail ke enam fase pembelajaran dapat disajikan dalam Gambar 1

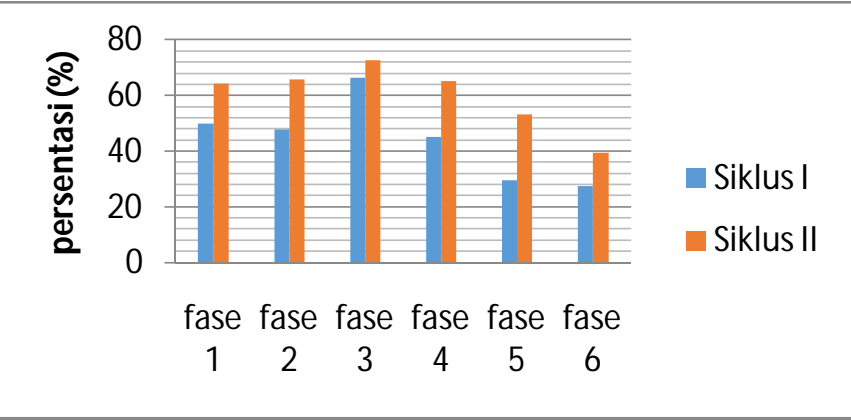

Gambar 1 Grafik aktivitas belajar siswa kelas X MIA 4 SMAN 22 Makassar setiap fase pembelajaran

Setiap aktivitas yang diamati pada tiap fase dikelompokkan ke dalam beberapa kelompok indikator aktivitas yaitu visual, oral, writingdan mental. Berdasarkan hasil penyajian dan analisis aktivitas belajar siswa secara teori (dapat dilihat pada Lampiran III), diperoleh persentase rata-rata aktivitas secara teori pada siklus II yaitu64.73\%.Rincian data kuantitatif hasil observasi aktivitas belajar siswa secara teori dapat dilihat pada Tabel 6.

Tabel 6 Hasil observasi aktivitas belajar siswa secara teori pada siklus II

\begin{tabular}{|c|c|c|}
\hline Indikator Aktivitas & Persentase(\%) & Predikat \\
\hline Visual Activities & 73.43 & Baik \\
\hline Oral Activities & 55.68 & Cukup \\
\hline Writing Activities & 68.94 & Baik \\
\hline Mental Activities & 70.31 & Baik \\
\hline
\end{tabular}

Secara detail keempat indikator aktivitas secara teori ini disajikan dalam Gambar 2 


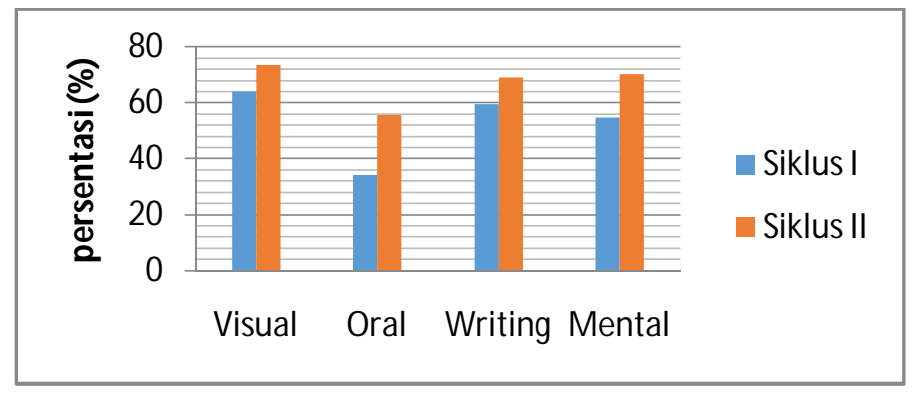

Gambar 2 Grafik aktivitas belajar siswa kelas X MIA 4 SMAN 22 Makassar secara teori setiap indikator aktivitas

Hasil di atas menunjukkan bahwa persentase aktivitas belajar telah meningkat jika dibandingkan dengan siklus I. Hal ini juga dibuktikan dengan meningkatnya kategori aktivitas belajar siswa untuk tiap aspek yang diobservasi. Data ini menunjukkan bahwa tindakan-tindakan yang dilakukan pada siklus II dapat meningkatkan aktivitas belajar siswa.

Model pembelajaran think pair sharedengan pendekatan scientific dapat meningkatkan aktivitas dan hasil belajar siswa dalam proses pembelajaran yang dilakukan melalui siklus I dan siklus II. Berdasarkan hasil analisis kualitatif aktivitas siswa pada siklus I dan II, terlihat model pembelajaran think pair sharedengan pendekatan scientific dapat mengubah kebiasaan siswa seperti kurangnya rasa percaya diri saat diminta untuk menyampaikan pertanyaan, pendapat maupun tanggapan, bahkan rasa tidak percaya diri untuk mengerjakan soal-soal yang diberikan sehingga timbul kebiasaan untuk mengharapkan bantuan dari teman dan hanya berpatokan pada buku saja. Hal ini terjadi karena model pembelajaran model pembelajaran think pair sharedengan pendekatan scientific merupakan jenis pembelajaran mengharapkan siswa dapat saling bekerja sama dan bertukar pikiran (interaksi), siswa akan memiliki rasa tanggung jawab atas apa yang dikerjakan dan dengan adanya interaksi yang baik maka menumbuhkan aktivitas yang baik pula. Sedangkan penggunaan pendekatan scientific merupakan cara melaksanakan proses pembelajaran yang didasarkan pada fenomena dan fakta yang terjadi melalui proses hasil kegiatan mengamati, menanya, menalar, mencoba, dan mengomunikasikan.

Persentase aktivitas belajar siswa siklus I menunjukkan bahwa aktivitas belajar siswa masih sangat rendah yaitu $42.18 \%$ dengan kategori cukup dan aktivitas belajar siswa secara teori yaitu 50.08\% dengan kategori cukup. Hasil ini memperlihatkan bahwa dalam proses pembelajaran, masih banyak siswa yang tidak sepenuhnya melakukan kegiatan yang berhubungan dengan aktivitas belajar sesuai model pembelajaran yang diterapkan.

Persentase rata-rata aktivitas belajar siswa dalam penelitian ini juga mengalami peningkatan dalam setiap fasenya. Berdasarkan hasil penyajian dan analisis data aktivitas 
belajar siswa pada tiap fase meningkat dari siklus I yaitu $42.18 \%$ dengan kategori cukup menjadi $62.06 \%$ dengan kategori baik pada siklus II. Hal ini menunjukkan penerapan model pembelajaran think pair share dengan pendekatan scientific dapat meningkatkan aktivitas belajar siswa.

Tindakan-tindakan yang dilakukan peneliti pada siklus II dapat dikategorikan efektif untuk meningkatkan aktivitas belajar siswa. Hal ini dapat dilihat pada tabel 4.6 yang menunjukkan persentase rata-rata aktivitas belajar siswa meningkat menjadi62.06\% dengan kategori baik dan Tabel4.7 yang menunjukkan persentase rata-rata aktivitas belajar siswa secara teori meningkat menjadi $64.73 \%$ pada siklus II dalam penelitian ini.

\section{PENUTUP}

\section{Kesimpulan}

Berdasarkan penelitian yang telah dilakukan, maka dapat disimpulkan sebagai berikut:

1. Langkah-langkah pada setiap fase model pembelajaran think pair sharedengan pendekatan scientific yang dapat meningkatkan aktivitas belajar siswa kelas X MIA 4 SMA Negeri 22 Makassar yaitu sebagai berikut:

a. Fase I pendahuluan dilakukan dengan cara menegaskan bahwa keberanian mengungkapkan pendapat di depan umum sangat penting dan juga masuk dalam komponen penilaian guru

b. Fase IIthink dilakukan dengan cara menegaskan bahwa siswa harus memiliki pertanyaan dari materi yang tidak pahami dari apa yang diamati (Mengamati dan Menanya), dan menegaskan bahwa sebelum berdiskusi dengan pasangannya masing-masing terlebih dahulu semua siswa harus menuliskan jawaban sendiri (Menalar dan Mencoba).

c. Fase IIIpair dilakukan dengan cara mengacak kembali pasangan belajar agar siswa terlatih untuk bekerja sama dengan semua teman kelas mereka dan menekankan kepada semua pasangan belajar agar lebih memperhatikan dan membimbing pasangannya saat diskusi sehingga setiap siswa mengetahui jawaban dari semua soal yang diberikan (Mengomunikasikan).

d. Fase IVshare dilakukan dengan cara menegaskan bahwa bagi siswa yang berani menyampaikan hasil pemikiran dengan pasangannya ke seluruh pasangan akan diberi nilai tambahan dan hadiah dan akan dilakukan penunjukkan jika tidak ada yang berani mengemukakan pendapatnya serta meminta siswa untuk menuliskan jawaban yang telah disepakati oleh seluruh pasangan (Mengomunikasikan). 
e. Fase V evaluasi dilakukan dengan cara menunjuk secara acak siswa untuk menjawab pertanyaan yang diberikan oleh guru secara mandiri

f. Fase VI penutup dan penghargaan dilakukan dengan cara memberikan penghargaan dalam bentuk pujian dan hadiah bagi siswa yang paling aktif dan menegaskan bahwa kesimpulan diakhir pembelajaran merupakan bagian yang terpenting untuk bisa lulus dalam tes akhir hasil belajar dan guru mengecek catatan siswa.

2 Persentase aktivitas belajar siswa meningkatdari 42,18\%pada siklus I dengan kategori cukup menjadi $62,06 \%$ pada siklus II dengan kategori baik. Sedangkan Persentase hasil belajar siswa yang mencapai nilai ketuntasan meningkat dari $46,87 \%$ pada siklus I menjadi $78,12 \%$ pada siklus II.

\section{Saran}

Berdasarkan hasil penelitian dan kekurangan yang dihadapi peneliti selama melakukan penelitian, maka beberapa saran yang dapat disampaikan adalah sebagai berikut:

1. Bagi guru, khususnya guru kimiaagar mempertimbangkan penerapan model pembelajaran think pair share dengan pendekatan scientific sebagai salah satu alternatif untuk meningkatkan aktivitas dan hasil belajar siswa.

2. Kekurangan yang dialami pada penelitian ini yaitu penggunaan waktu yang lebih lama sehingga guru sebaiknya memaksimalkan proses pembelajaran dengan memperhatikan pembagian waktu dengan baik agar waktu pelaksanaannya tidak melebihi waktu yang telah ditentukan.

3.

\section{DAFTAR PUSTAKA}

Chotimah,Husnul. 2009. Strategi-Strategi Pembelajaran untuk penelitian Tindakan Kelas. Malang:Surya Pena Gemilang.

Pembelajaran Kimia di SMA Negeri 10 Palembang. http://kntia.unsri.ac.id. Diakses pada tanggal 23 Maret 2014.

Kurinasih dan Berlin Sani. 2014. Implementasi Kurikulum 2013: Konsep dan Penerapan. Surabaya: Kata Pena.

Mufidah,lailatul dkk.2013.Penerapan model pembelajaran kooperatif tipe TPS untuk meningkatkan aktivitas belajar siswa pada pokok bahasan matriks.Jurnal pendidikan matematika.Vol.1,No.1 
Permendikbud. 2013. Jurnal Lampiran Peraturan Menteri Pendidikan dan Kebudayaan Republik Indonesia Nomor 65 Tahun 2013 Tentang Standar Proses Pendidikan Dasar dan Menengah.

Wahyuni, Sri.2012. Penerapan Model pembelajaran kooperatif Tipe TPS(Think Pair Share) untuk Meningkatkan Hasil Belajar Matematika Kelas VIIA MTs Ma'rif Tumbel Gani Bantaeng Tahun Ajaran 2011/2012.

Yuliawati. 2009. Keefektifan Pembelajaran dengan Model Koperatif Tipe Think-pair-share (TPS) Terhadap Sub Pokok Bahasan Hidrokarbon Pada Siswa Kelas X SMA Negeri 3 Palangkaraya Tahun Pelajaran 2008/2009.Skripsi dipublikasikan 